\title{
European Data Protection Regulation and Online New Media: Mind the Enforcement Gap
}

\section{DAVID ERDOS $^{1}$}

\begin{abstract}
Data Protection Authorities (DPAs) play a critical role in shaping and applying the regulation applicable to online media expression within the European Economic Area. Drawing on seven ubiquitous types of online new media actors, a comprehensive survey of these authorities was undertaken. Tallying with its strong symbolic importance in Europe, this research found that European DPAs generally adopt an expansive interpretation of data protection and constrained understanding of freedom of expression in this space. In contrast, data protection enforcement has been weak and lacking in harmonization. Except for street mapping services, each type of online media actor had only faced relevant enforcement action from a minority of these agencies. DPA financial resourcing is very limited. Notwithstanding the development of DPA 'network governance' through the Article 29 Working Party, only DPAs with a particularly extensive interpretative stance proved likely to have engaged in extensive enforcement activity. It remains unclear what difference the General Data Protection Regulation will make to resolving this enforcement gap and its related problems.
\end{abstract}

\footnotetext{
${ }^{1}$ University Lecturer in Law and the Open Society and WYNG Fellow in Law, Trinity Hall, University of Cambridge, Trinity Lane, Cambridge, CB2 1TJ, doe20@ cam.ac.uk. I would like to record my appreciation to the research assistants and others who aided the research presented, the DPAs who participated in the survey and the British Academy whose funding made it possible. I particularly thank Jeff Ausloos, Maja Brkan and Brendan Van Alsenoy who provided comments on work in progress, Vaughan Connolly for checking some of the statistics and Ann Kristin Glenster for assistance in preparing the final manuscript. Any errors remain my own.
} 
Although still sometimes unfairly dismissed as "marginal", ${ }^{2}$ European data protection centred on Data Protection Directive 95/46 (herein Directive 95/46) ${ }^{3}$ has emerged as "the central field for the development of privacy law and policy" ${ }^{4}$ Moreover, whilst it can be seen as heralding a "remarkable expansion in human rights", 5 the substantive framework established by the Directive 95/46 sits in strong tension with the freedom to impart information especially through new, online media. Google Spain dramatically highlighted this tension in the area of search engine indexing. ${ }^{6}$ However, it arises similarly across an ever more variegated and important new or online media landscape from blogging to social networking to street mapping. Directive 95/46 additionally "mandated the creation of powerful national independent regulatory authorities - data privacy [or data protection] authorities that monitor and enforce these rules" ${ }^{\prime 7}$ across the European Economic Area (EEA). ${ }^{8}$ As the EU Agency for Fundamental Rights has emphasised, these agencies are "the main actors protecting data protection rights, [and] play a crucial role in processing the overwhelming majority of data protection complaints". ${ }^{9}$ In light of the critical role of the DPAs and the increasing centrality of online media activity, this article presents research on the interpretative stance, enforcement efforts and enforcement capacity of these agencies in this ever more ubiquitous area. It principally draws on the results of a 2013 survey which secured unprecedented access to these regulators; in sum, twenty five,

\footnotetext{
${ }^{2}$ B. Leveson, An Inquiry into the Culture, Practices and Ethics of the Press (2012).

${ }^{3}$ Directive 95/46/EC of the European Parliament and of the Council of 24 October 1995 on the protection of individuals with regard to the processing of personal data and on the free movement of such data.

${ }^{4}$ P. Keller, European and international media law: liberal democracy, trade, and the new media (2011) 331.

${ }^{5}$ A. Newman, 'Building transnational civil liberties: Transgovernmental entrepreneurs and the European Data Privacy Directive’ 62 International Organization (2008) 103 at 119.

${ }^{6}$ Google Spain, Google v Agencia Española de Protección de Datos, Mario Costeja González (C-131/12) EU:C:2014:317).

${ }^{7}$ Newman, op. cit., n. 5, p. 104.

${ }^{8}$ Under the Agreement on the European Economic Area, the Directive extends to Iceland, Liechtenstein and Norway which, together with the EU, make up the Economic Area (EEA). See EEA Joint Committee, Decision No. 83/1999 of 25 June 1999 amending Protocol 37 and Annex XI (Telecommunication Services). The precise relationship between the legal duties of Iceland, Liechtenstein and Norway and both related legal provisions such the protection of data protection within the EU treaties and interpretations of data protection by the Court of Justice of the European Union remains a matter of great complexity, the consideration of which is beyond the scope of this article. Following the results of a referendum on 24 June 2016, the UK Government is now committed to the UK (and with the UK's intra-EU overseas territory of Gibraltar) leaving the EU. The UK Government's position on continued membership of the EEA remains more ambiguous. For now, however, the UK remains a full member of the EU, as it was when the data presented in this article was collated.

${ }^{9}$ European Union, Agency for Fundamental Rights, Access to Data Protection Remedies in EU Member State (2013), 49 «http://fra.europa.eu/sites/default/files/fra-2014-access-data-protection-remedies_en_0.pdf».
} 
that is approximately $80 \%$, of national EEA DPAs participated, together with a further six operating at the regional level. ${ }^{10}$

The survey results demonstrated that European DPAs overwhelmingly hold data protection norms to be strongly engaged across the online media space. Such an onerous interpretative stance reflects the symbolic centrality of data protection within the now maturing area of EU fundamental rights coupled with the role DPAs play as "the guardians" $" 11$ of this framework, both nationally ${ }^{12}$ and in the pan-European Article 29 Working Party. ${ }^{13}$ In contrast, as will be explored below, enforcement has been both weak and lacking in harmonization. Whilst the generally low level of enforcement may be linked to the meagre financial resources of the DPAs, divergences between them relate rather to continuing disparities in their interpretative stance. Only DPAs with an unusually strong ideological commitment to data protection proved likely to have engaged in extensive enforcement activity, a fact which may be related to the risks this entails in terms of potentially taking on powerful interests such as Google or Facebook and garnering negative publicity. A focus in some of the literature on often largely paper-based processes of "networked governance"14 within the Working Party may, therefore, overemphasise the level of practical effectiveness and harmonization that this regime has achieved. Whilst the General Data Protection Regulation recognises some of these challenges, it is unclear how effective the reforms it stipulates will prove in practice.

The rest of this article is structured as follows. The first section briefly introduces the essential legal context including the default structure and substance of Directive 95/46, the original debate on its interface with public freedom of expression and the evolution of thinking on this issue consequent to the seminal case of Lindqvist. ${ }^{15}$ The next then reviews the existing literature and outlines the specific research questions posed, and the methodology adopted, in this study. The following two sections present and then analyse the general pattern of results. The article then turns

\footnotetext{
${ }^{10}$ The survey entitled 'DPA Survey on Data Protection and the Open Society' was carried out by myself and made possible as a result of funding from the British Academy.

${ }^{11}$ Commission v Germany (C-518/07) EU:C:2010:125 at [23].

${ }^{12}$ Directive 95/46, art. 28.

${ }^{13}$ Directive 95/46, art. 29.

${ }^{14}$ Newman, op. cit., n. 5, p. 182.

${ }^{15}$ Lindqvist, Criminal Proceedings Against Bodil (C-101-01), EU:C:2003:596.
} 
to explore the significant differences between the different jurisdictions as regards DPA enforcement, focusing on whether these might be explained by divergences in the level of financial resourcing of these agencies and/or by variation in the stringency of their interpretative stance. The penultimate section explores the future shape of European data protection here, whilst the final one offers some brief conclusions.

\section{THE LEGAL AND POLICY CONTEXT}

\section{The general Data Protection framework}

Since the inception of data protection consequent to the development of computerized information and communication technology, Europe has played a groundbreaking role in championing its importance as an issue of fundamental rights. A Council of Europe Data Protection Convention was finalized as early as $1981^{16}$ and in 1995 the European Union agreed to a Data Protection Directive 95/46 designed to "give substance and amplify" the Convention's provisions. ${ }^{17}$ In 2000, data protection was also recognised alongside a traditional right to privacy as a distinct right within the new EU Charter. ${ }^{18}$ The Treaty of Lisbon, which entered into force in December 2009, granted the Charter the same legal status as the EU Treaties. ${ }^{19}$ Uniquely, it also separately set out a right to data protection in the treaties themselves. ${ }^{20}$

The material, purposive and substantive reach of European data protection as encapsulated in the framework Directive 95/46 are far-reaching. Absent specific exemption under Article 3.2, its material scope encompasses the "processing of personal data wholly or partly by automatic means" as

\footnotetext{
${ }^{16}$ Convention for the Protection of Individuals with regard to Automatic Processing of Personal Data (ETS 108).

${ }^{17}$ Directive 95/46, recital 11. The extension of the substantive provisions of the Directive to three non-EU members of the EEA (Iceland, Liechtenstein and Norway) is based European Economic Area law (see op. cit., n. 8). The precise relationship between these jurisdictions are both related legal provision such as the protection of data protection in the EU Charter and treaties and interpretations on the law by the Court of Justice of the European Union remains a matter of great complexity, the consideration of which it beyond the scope of this article.

${ }^{18}$ Charter of Fundamental Rights of the EU (hereinafter EU Charter), arts 7 and 8.

19 TEU, art. 6 (1).

${ }^{20}$ TFEU, art. 16.
} 
well as in certain structured, manual filing systems. ${ }^{21}$ The key terms here are all defined broadly. "[P]ersonal data" refers to "any information relating to an identified or identifiable natural person ('data subject')" and "processing ... by automatic means" includes "any operation" performed digitally including consultation, dissemination and erasure. ${ }^{22}$ Meanwhile, its purpose is to "protect the fundamental rights and freedoms of natural persons, and in particular their right to privacy", while at the same time prohibiting restrictions on the free flow of such personal data within Europe for reasons connected with such protection. ${ }^{23}$ The Directive also stresses that the level of protection achieved must be both "equivalent" 24 and "high". ${ }^{25}$ Reflecting these wide and ambitious purposes, the default substance of the regime requires that all "controllers" - that is anybody "who alone or jointly with others determines the purposes and means of the processing of personal data"26 - ensure that their data processing comply with an extensive set of data protection principles, ${ }^{27}$ detailed rules relating to data subject transparency ${ }^{28}$ and sensitive data ${ }^{29}$ and, finally, a range of data security and other control mechanisms designed to secure discipline in data processing. ${ }^{30}$ Turning to the Directive's supervisory system, although a right to a judicial remedy ${ }^{31}$ and individual compensation ${ }^{32}$ must be made available, in reality "very few data protection cases are initiated"33 and courts play a "small role" in this area $).{ }^{34}$ Instead, the central and "essential component" $" 35$ of this system rests on the establishment in each Member State of one or more independent DPAs which have a duty to monitor application of the law and hear claims by data subjects; in turn, they must also be endowed with wideranging powers of investigation and intervention. ${ }^{36}$ Finally, representatives of these agencies must

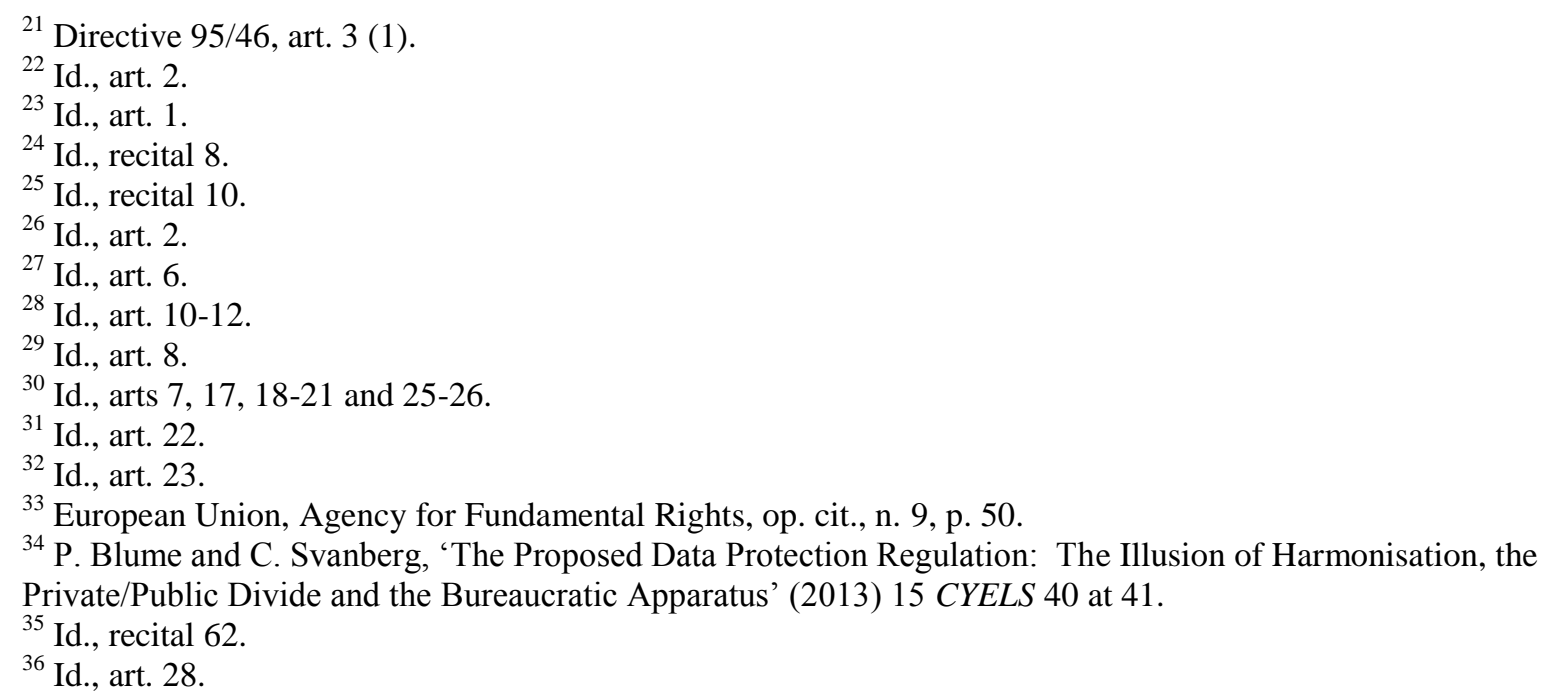


cooperate together including in the pan-European Working Party ${ }^{37}$ which is charged with promoting "uniform application" ${ }^{38}$ of Directive 95/46 across the EEA. The centrality of the DPAs is reflected in the fact that one of the few elements of the regime specifically elucidated in the EU Charter is that "[c]ompliance ... shall be subject to control by an independent authority". ${ }^{39}$

\section{Freedom of Expression under Directive 95/46}

The exercise of freedom of expression undoubtedly has the potential to seriously and negatively impact on the privacy and other rights and freedoms which data protection is established to defend. At the same time, the default data protection provisions outlined above also plainly have the potential to seriously interfere with free speech. Clearly, therefore, the law should address the tension between these two sets of rights. However, whilst the need for this was explicitly recognised in Article 9 of Directive 95/46, this was true only as regards processing "carried out solely for journalistic purposes or the purpose of artistic or literary expression". Moreover, even within this special purposes area, Member States were to provide for derogations "only if they are necessary to reconcile the right to privacy with the rules governing freedom of expression”. Recital 37 further clarified that there should be no qualification to the requirements of data security and "at least the supervisory authority responsible for this sector should ... be provided with certain ex-post powers". Although other parts of the Directive empowered Member States to adopt more limited derogations where "necessary ... to safeguard ... the rights and freedoms of others", ${ }^{40}$ freedom of expression was rarely discussed in this context.

Notwithstanding Article 9's dichotomous conceptualization of this issue, the Lindqvist case highlighted early on in the Directive's history that the relationship between data protection and

\footnotetext{
${ }^{37}$ Established under art 29 of the Directive, this group comprises a voting DPA representative from each of the EU Member States and the pan-EU European Data Protection Supervisor, together with a non-voting representative of the European Commission. The non-EU EEA DPAs also participate in the Working Party's activities as observers (see EEA Joint Committee, Decision 83/1999, art. 2 (op. cit., n. 8)).

${ }^{38}$ Directive 95/46, art. 30 (1) (a).

${ }^{39}$ EU Charter, art. 8 (3).

${ }^{40}$ Directive $95 / 46$, art. $13(\mathrm{~g})$. See also articles 8.4 and 8.5 for optional derogations related to the sensitive data rules.
} 
freedom of expression was more complex. This case considered the potential data protection obligations arising from Mrs. Lindqvist's publication on her personal internet site of "personal data of a number of people working with her on a voluntary basis in a parish of the Swedish Protestant Church" ${ }^{41}$ Although Mrs. Lindqvist claimed that she was excluded from this law, the European Court of Justice strongly rejected this. In particular, it held that Directive's exception clause ${ }^{42}$ exempting activities 'outside the scope of Community law' was limited to the "activities of the State or of State authorities", ${ }^{43}$ whilst this clause's similar exclusion of 'purely personal or household activity' "clearly" did not encompass "the processing of personal data consisting in publication on the internet so that those data are made accessible to an indefinite number of people". ${ }^{44}$ The Court also refused to support the claim by the European Commission (which along with several Member States intervened in this case) that the website constituted "an artistic and literary creation within the meaning of Article 9" ${ }^{45}$ However, notwithstanding the United Kingdom's oblique suggestion that general data protection provisions might legitimately apply in full here,${ }^{46}$ it ultimately supported the proposition that "Mrs Lindqvist's freedom of expression ... [has] to be weighed against the protection of the private life of individuals about whom Mrs Lindqvist has placed data on her internet site" and that it was the responsibility of both "authorities and courts" to ensure that this happened. ${ }^{47}$

Although certain aspects of the Lindqvist judgment, notably as regards the material scope of the Directive, were apparently peremptory, the various arguments raised in the case have remained live at a practical level. In any case, similar disputes must be addressed not just in relation to amateur individual publication but as regards the whole range of online media expressive activity.

\footnotetext{
${ }^{41}$ Lindqvist, op. cit., n. 15 at [2].

42 Directive 95/46, art. 3 (2).

${ }^{43}$ Lindqvist, op. cit., n. 15 at [43].

${ }^{44}$ Id. at [47]. Lindqvist additionally argued that the Directive was contrary to the general principle of freedom of expression enshrined within EU law. This, however, was also rejected by the Court (Id. at [90]).

${ }^{45}$ Id. at [33].

${ }^{46}$ Id. at [55].

${ }^{47}$ Id. at [86].
} 


\section{EXISTING LITERATURE, RESEARCH QUESTIONS AND METHODLOGY}

The growing literature on the European data protection provides a good elucidation of the way in which it "relies on a network of national regulators embedded within a pan-European cooperative structure to oversee and monitor data privacy rules". ${ }^{48}$ It is, however, marked by strong disagreement as to the extent to which the goals of the regime have been achieved. For example, whilst Newman states that "European integration efforts have clearly resulted in a significant convergence among national enforcement regimes", ${ }^{49}$ Blume and Svanberg claim that "there can be little doubt that Directive 95/46 has not achieved real harmonisation". ${ }^{50}$ Nevertheless, rather surprisingly given its growing importance and complexity, there is almost no work exploring at an empirical level the interface between this European data protection regime and online media expression.

This article seeks to address this lacunae by systematically analysing the interpretative stance, enforcement extent and enforcement capacity of DPAs in this area. In doing so, it primarily draws on the results of a survey on these issues which was sent to both national and sub-national EEA DPAs, ${ }^{51}$ initially in March 2013, with replies being received until the end of July $2013 .{ }^{52}$ Responses were forthcoming from 25 (over $80 \%$ ) of national DPAs, together with a further six operating subnationally. This, therefore, provided a near comprehensive set of empirical data, providing a clear elucidation of the current data protection landscape for online media expression across Europe. In addition, it was recognised that, as regards reported enforcement action, it would be both useful and practicable to engage in some cross-checking of the results against public domain material. Using

\footnotetext{
${ }^{48}$ Newman, op. cit., n. 5, p. 182.

${ }^{49}$ Id., p. 185.

${ }^{50}$ P. Blume and C. Svanberg, op. cit., n. 34, p 40.

${ }^{51}$ Sub-national DPAs have been established in Spain and Germany as well as in Gibraltar, a separate jurisdiction within the EU but one for which the UK remains responsible.

52 Given that the survey as a whole explored a whole range of matters related to the tension between data protection and openness, no attempt was made to contact the specialist media regulators (the Press Council and Inspector of Journalist Ethics respectively) which in Lithuania and Denmark exercise limited regulatory powers in the media sector even in relation to journalism. In fact, however, the Lithuanian DPA response made clear that It had filled out relevant responses in cooperation with the Inspector of Journalist Ethics. Meanwhile, the Danish DPA did not participate in the survey.
} 
language experts for the various jurisdictions, a review was therefore made of relevant material readily available on the websites of all the DPAs responding to the survey.

Turning to the construction of the survey itself, 'media expression' was conceptualized to refer to mass communication or, in other words, forms of disseminating information to a potentially large and generally indefinite number of people. Meanwhile, the reference to 'new' or 'online' focused on "those methods and social practices of communication ... that have developed using the digital, multimedia, networked computer and the ways in which this machine is held have transformed work in other media". ${ }^{53}$ This definition was capacious enough to include both practices focused principally on the relatively static 'web page' (e.g. blogging) and newer 'Web 2.0' models which seek to capitalize even more explicitly on the internet's network attributes, thereby enhancing the 'spreadable' nature of online communication as well as the participative nature of its production (e.g. social networking). ${ }^{54}$

As regards the questions linked to the interpretative stance of the DPAs, the survey probed these agencies on their opinion as regards the following seven hypothetical scenarios, which were intentionally linked to seven types of online media actor which have become both well-established and ubiquitous:

1. Newspaper archive - "A searchable online newspaper archive publishes a newspaper story originally published a decade ago concerning a living individual."

2. Individual blogger - "In his spare time, an individual publishes a blog that discusses and disseminates gossip about various celebrities. It is freely available on the Internet and visited by several hundred people a week."

3. Internet rating website - "A company establishes a website freely available on the Internet allowing individuals to 'rate' and add comments about their teachers."

4. Individual on social networking site - "A member of a Social Networking Site (SNS), the membership of which is generally open to individuals worldwide, 'tags' a photo of an

\footnotetext{
${ }^{53}$ M. Lister, J. Dovey, S. Giddings, I. Grant, and K. Kelly, New Media: A Critical Introduction (2003) 2.

${ }^{54}$ For a general discussion see C. Fuchs, Social Media: A Critical Introduction (2014) 31-49.
} 
identified individual and makes an informed decision to make this freely available to all members of the site."

5. Social networking site - "The Social Networking Site (SNS) is contacted directly by the same identified individual as above [i.e. the data subject mentioned in scenario 4 above] who claims that the Site itself is a Data Controller in relation to this processing."

6. Internet search engine - "A company provides a service allowing people to search the information sources of the public Internet (including on identified individuals) through a web-based search engine."

7. Street mapping service - "A street mapping service produces maps with street-level photographic images including pictures of individuals, motor vehicles and homes."

Although free-text responses were also permitted, DPAs were invited to indicate, in relation to each of the scenarios above, which one of these standardized statements was considered correct:

a. Data protection does not apply.

b. Data protection applies, but the activity in question must benefit from all the special derogations and exemptions for journalism, art and literature envisaged in Article 9 of Directive 95/46/EC.

c. The general provisions of data protection apply, but must be interpreted with regard for other fundamental rights including freedom of expression.

d. The general provisions of data protection law apply in full.

These pre-formulated statements attempted to crystallize the four broad approaches to the interface between public expression and data protection which, as outlined above, were put before the Court of Justice in Lindqvist. In essence, they represent ordered categories ranging from full exemption (option (a)) through to full application (option (d)) of the default data protection framework. As a result, it is possible to translate the responses onto a quantitative scale ranging from 0 (no application) to 1 (full application) of data protection. ${ }^{55}$

\footnotetext{
${ }^{55}$ Here (a) is equal to 0 , (b) to 0.33 , (c) to 0.67 and (d) to 1 .
} 
Turning to questions related to enforcement, the survey probed DPAs both on their enforcement activity, measured in terms of the extent of enforcement they had undertaken, and their enforcement capacity, measured in terms of the financial resources they had at their disposal. As regards enforcement activity, DPAs were invited to indicate what action (if any) they had taken since the transposition of Directive 95/46 as regards various types of activity connected to publication carried out by each of the online media actors specified above. Four responses were possible:

a. A nil-return indicating that no enforcement action had been taken at all.

b. An indication that action had been taken but only in relation to the use of material obtained without proper authorization from another data controller.

c. An indication that action had been taken but only in relation to processing activity not related to material obtained without proper authorization from another data controller.

d. An indication that action had been taken both in relation to the use of material obtained without proper authorization from another data controller and in relation to another type of processing activity.

These four options also represent ordered categories measuring, in this case, the divergent extent of data protection enforcement. ${ }^{56}$ An outcome of no enforcement (option (a)) is obviously the least extensive. Meanwhile, whilst option (b) signifies some action has been taken, this is expressly limited to the use of information obtained without permission from another controller. This latter controller will likely be processing for purposes which would be undermined by publication (e.g. medical care in the case of, say, a doctor's practice) and the unauthorized obtaining of the information will often require recourse to invidious mechanisms such as corruption or blagging. ${ }^{57}$ Therefore, enforcement in this context will in principle constitute less of a direct interference with exclusively new media publication than action in other contexts (option (c)) which will necessarily involve wider categories of information, most of which is likely either to have been obtained with consent (e.g. an interview

\footnotetext{
${ }^{56}$ The meaning of 'enforcement action' itself was not explicitly defined in the survey. However, for the purposes of the cross-check on DPA websites, this was taken to refer to any form of action which went beyond mere investigatory action or the issuing of 'soft' non-binding guidance to data controllers.

${ }^{57}$ UK Information Commissioner's Office What price privacy? The unlawful trade in confidential personal information (2006).
} 
transcript) or to have been self-generated by the publisher themselves (e.g. a photographic image).

Finally, taking action in both these contexts (option (d)) self-evidently constitutes the most extensive enforcement possible. Given this, it is similarly possible to translate these responses on to a $0-1$ quantitative scale.

Turning lastly to the question of financial resourcing, DPAs were asked to specify their annual budget dedicated to data protection issues. Where, as is regularly the case, part of the DPA's budget was used to further other objectives such as freedom of information, ${ }^{58}$ DPAs were specifically invited to estimate that part of the budget allocated to data protection.

\section{STANDARDIZED RESULTS OF THE DATA PROTECTION AUTHORITY SURVEY}

As noted above, some 31 DPAs responded to the survey, 25 of which operated at the national and 6 at the regional level. However, as regards interpretative stance, the UK DPA declined to provide any answers, whilst the Netherlands DPA only provided an answer in relation to two out the seven actors. ${ }^{59}$ Moreover, approximately $10 \%$ of the other answers were received in nonstandardized free-text form. These answers are excluded from the presentation of results in this section and the analysis in the next. In contrast, later discussion focusing on divergences between different European jurisdictions as regards DPA enforcement utilizes quasi-standardized responses which were imputed in place of these free-text answers. Further details on this are provided below. Turning to the enforcement dimension, a complete set of responses was received here, although two

\footnotetext{
${ }^{58}$ Such a merger of functions is a feature not only of Germanic and UK information law regulation but also of other jurisdictions including Hungary, Malta and Slovenia.

${ }^{59}$ The UK DPA justified its non-response on the basis that it considered "it would be unhelpful to attempt to offer a general view of the application of the law to situations where the outcome will necessarily be factspecific, and where we would need additional background information in order to express a view". Similarly, the Dutch DPA stated "most likely because our work has always been a very case-by-case approach" it was unable to respond fully "[s]ince the questions unfortunately don't give enough facts or the multiple choice answers were not the answer we would give".
} 
DPAs technically provided a response in their own words ${ }^{60}$ and two others provided some additional free-text specification. ${ }^{61}$

\section{Interpretative Stance and Enforcement Extent}

The tables overleaf set out general information on the standard responses received from DPAs in relation to their interpretative stance (Table One) and the extent of their enforcement action (Table Two). In each case, both the percentage and total number of responses falling within each of the four standardized categories is specified, with the modal category are also highlighted in bold. The last column then sets out an interpretation score and an enforcement score respectively. These are computed from the average of the numeric version of all the categorical responses received in relation to each online media actor. The standard deviation of these responses is also calculated. Finally, the last row provides combined information on the responses as regards all seven online media actors.

\footnotetext{
${ }^{60}$ In sum, the German federal DPA stated that it was "not competent in supervising data protection the private sector apart from telecommunication and postal services provides" and that therefore the questions "could be answered by the data protection authorities of the German Laender only". Meanwhile, the UK DPA stated "[w]e have not taken action in cases involving the groups specified, in relation to their unlawful obtaining of personal data or the context of processing for publication". Given that both responses clearly disclosed that the DPA not itself enforced in this area, both were simply coded zero as regards all the relevant actors.

${ }^{61}$ The Austrian DPA, which in any case reported some form of enforcement against all the new media actors specified, stated that its "list is probably incomplete as we are unable to search all case files of the last decade. It is quite likely that action has been taken against any kind of actor at least once". Meanwhile, the Bulgarian DPA stated that its enforcement action against an individual on a social networking site was "in his/her capacity as personal data controller".
} 
Table One: Interpretative Stance vis-à-vis Online Media Expression - Standard DPA Responses

\begin{tabular}{|c|c|c|c|c|c|}
\hline Online Media Actor (n) & $\begin{array}{c}\text { Category } \\
\text { a/0 } \\
\text { Exempt }\end{array}$ & $\begin{array}{c}\begin{array}{c}\text { Category } \\
\text { b/0.33 }\end{array} \\
\text { Art. } 9 \text { Special } \\
\text { Purposes }\end{array}$ & $\begin{array}{c}\text { Category } \\
\text { c/0.67 } \\
\text { Regard for } \\
\text { Expression }\end{array}$ & $\begin{array}{c}\text { Category } \\
\text { d/1 } \\
\\
\text { Full } \\
\text { Application }\end{array}$ & $\begin{array}{c}\text { Interpretation } \\
\text { Score } \\
\text { (Standard } \\
\text { Deviation) }\end{array}$ \\
\hline $\begin{array}{l}\text { (1) Newspaper Archive } \\
(n=25)\end{array}$ & $12 \%(3)$ & $48 \%(12)$ & $32 \%(8)$ & $8 \%(2)$ & $0.45(0.26)$ \\
\hline $\begin{array}{l}\text { (2) Individual Blogger } \\
(\mathrm{n}=\mathbf{2 5})\end{array}$ & $12 \%(3)$ & $24 \%(6)$ & $60 \%(15)$ & $4 \%(1)$ & $0.52(0.25)$ \\
\hline $\begin{array}{l}\text { (3) Internet Rating } \\
\text { Website }(n=30)\end{array}$ & $3 \%(1)$ & $0 \%(0)$ & $50 \%(15)$ & $47 \%(14)$ & $0.80(0.22)$ \\
\hline $\begin{array}{l}\text { (4) Individual on Social } \\
\text { Networking Site }(n=25)\end{array}$ & $16 \%(4)$ & $4 \%(1)$ & $32 \%(8)$ & $48 \%(12)$ & $0.71(0.36)$ \\
\hline $\begin{array}{l}\text { (5) Social Networking } \\
\text { Site }(n=26)\end{array}$ & $0 \%(0)$ & $4 \%(1)$ & $23 \%(6)$ & $73 \%(19)$ & $0.89(0.18)$ \\
\hline $\begin{array}{l}\text { (6) Internet Search } \\
\text { Engine }(n=26)\end{array}$ & $8 \%(2)$ & $0 \%(0)$ & $12 \%(3)$ & $81 \%(21)$ & $0.88(0.28)$ \\
\hline $\begin{array}{l}\text { (7) Street Mapping } \\
\text { Service }(n=29)\end{array}$ & $0 \%(0)$ & $0 \%(0)$ & $7 \%(2)$ & $93 \%(27)$ & $0.98(0.08)$ \\
\hline Average & $\underline{7 \%}$ & $\underline{11 \%}$ & $31 \%$ & $\underline{51 \%}$ & $0.75(0.23)$ \\
\hline
\end{tabular}

Table Two: Enforcement vis-à-vis Online Media Expression: Standard DPA Responses

\begin{tabular}{|l|c|c|c|c|c|}
\hline $\begin{array}{l}\text { Online Media Actor } \\
(\mathbf{n}=\mathbf{3 1})\end{array}$ & $\begin{array}{c}\text { Category } \\
\mathbf{a} / \mathbf{0} \\
\text { No } \\
\text { Enforcement }\end{array}$ & $\begin{array}{c}\text { Category } \\
\mathbf{b / 0 . 3 3} \\
\text { Unauthorized } \\
\text { Material Only }\end{array}$ & $\begin{array}{c}\text { Category } \\
\mathbf{c / 0 . 6 7} \\
\text { Other } \\
\text { Material Only }\end{array}$ & $\begin{array}{c}\text { Category } \\
\mathbf{d} / \mathbf{1} \\
\text { Unauthorized } \\
\text { and Other } \\
\text { Material }\end{array}$ & $\begin{array}{c}\text { Enforcement } \\
\text { Score } \\
\text { (Standard } \\
\text { Deviation) }\end{array}$ \\
\hline $\begin{array}{l}\text { (1) Newspaper Archive } \\
\text { (2) Individual Blogger }\end{array}$ & $\mathbf{5 8 \% ( 1 8 )}$ & $10 \%(3)$ & $13 \%(4)$ & $19 \%(6)$ & $0.31(0.40)$ \\
\hline $\begin{array}{l}\text { (3) Internet Rating } \\
\text { Website }\end{array}$ & $\mathbf{5 1 \% ( 1 6 )}$ & $3 \%(1)$ & $26 \%(8)$ & $19 \%(6)$ & $0.38(0.41)$ \\
\hline $\begin{array}{l}\text { (4) Individual on Social } \\
\text { Networking Site }\end{array}$ & $\mathbf{5 8 \% ( 1 8 )}$ & $6 \%(1)$ & $23 \%(7)$ & $13 \%(4)$ & $0.29(0.39)$ \\
\hline $\begin{array}{l}\text { (5) Social Networking } \\
\text { Site }\end{array}$ & $\mathbf{5 5 \% ( 1 7 )}$ & $3 \%(1)$ & $19 \%(6)$ & $23 \%(7)$ & $0.37(0.43)$ \\
\hline $\begin{array}{l}\text { (6) Internet Search } \\
\text { Engine }\end{array}$ & $\mathbf{7 4 \% ( 2 3 )}$ & $6 \%(2)$ & $13 \%(4)$ & $6 \%(2)$ & $0.17(0.32)$ \\
\hline $\begin{array}{l}\text { (7) Street Mapping } \\
\text { Service }\end{array}$ & $\mathbf{4 8 \% ( 1 5 )}$ & $6 \%(2)$ & $29 \%(9)$ & $16 \%(5)$ & $0.38(0.40)$ \\
\hline Average & $\underline{\mathbf{5 8 \%}}$ & $\underline{5 \%}$ & $\underline{21 \%}$ & $\underline{16 \%}$ & $\underline{0.31(0.39)}$ \\
\hline
\end{tabular}

Turning to the attempt to cross-check the data on enforcement with that readily available on DPA websites, it was found that the very different way in which regulators approached the issues of publicly reporting, retaining and collating information in this area made the collection of systematic and comparable datasets largely impossible. In particular, it was clear that many DPAs only 
publicized prominent as opposed to all examples of enforcement action and, in addition, only provided lists of such information from the past few years rather than since transposition of Directive $95 / 46 .{ }^{62}$ In the case of street mapping services, however, it did prove possible to collate generally comprehensive information. This reflected the fact that most enforcement here occurred in response to the roll-out across Europe of Google Street View (GSV) from 2008 onwards and was therefore both recent and had a relatively high-profile. In this case, action taken against GSV as regards its illegal collection of information from private individual's wi-fi connections was coded as enforcement in relation to the use of unauthorized material. Conversely, action against GSV (or in a few cases other street mapping services) as regards the recording and/or use of photographic images was coded as enforcement concerning other material. Even here, the complex manner in enforcement action against GSV was funnelled through the Hamburg DPA ${ }^{63}$ made coding impracticable in the case of the four German Länder survey respondents. ${ }^{64}$ The dataset from the remaining 26 DPA websites indicated that 11 DPAs (42\%) had taken no enforcement action here at all (category a/0), $2(8 \%)$ had taken enforcement action only in relation to unauthorized material, 8 DPAs (31\%) had taken action only in relation to other material (category c/0.67) and finally 5 DPAs (19\%) had taken action in both of these areas (category $\mathrm{d} / 1$ ). The enforcement score here is 0.42 and the standard deviation 0.40 . As can be seen from the second to last row of Table Two above, these figures are extremely similar to the ones reported by the DPAs in this case. ${ }^{65}$

\footnotetext{
${ }^{62}$ This later reality was the case, for example, as regards the Estonian DPA's website, which only provided a list of formal enforcement prescriptions from the past few years (Estonia, Eesti Andmekaitse Inspektsioon Ettekirjutused (2016) «http://www.aki.ee/et/menetluspraktika/ettekirjutused»).

${ }^{63}$ The authority with jurisdiction for the region within which GSV's German headquarters are located. This DPA was not amongst the survey respondents.

${ }^{64}$ It should also be noted that the Portuguese DPA kindly supplied documentation on formal action it had taken on 30 April 2013 against Google Street View. Whilst this information was not found during the collection of data from the Portuguese DPA website, it was later published on this site. It was, therefore, decided to take its contents into consideration when completing the public domain coding.

${ }^{65}$ This dataset was also correlated at the level of individual result level with the DPA survey returns on street mapping service enforcement. The Spearman's rho here was 0.774 with a two-tailed significance value of 0.00 .
} 


\section{Resourcing}

DPAs provided information on their annual budgets in a variety of forms. Although the great majority specified a figure in Euros, seven elected to respond using their local currency. ${ }^{66}$ Both the UK and Polish DPAs also explicitly indicated that their figure related to a year other than 2013 (the year of the survey). It was, therefore, necessary to normalize these figures as best as possible. This was achieved by using the average exchange rate for 2013 or, in the case of the UK and Poland, 2012 and 2011 respectively (the nearest full calendar year to that specified by the DPA). ${ }^{67}$ The special situation in Germany and Spain also had to addressed. ${ }^{68}$ Uniquely, these countries divide both funding and regulatory responsibility for supervising data protection between the federal and Länder/regional DPAs. In Germany the federal DPA is essentially responsible only for regulating the public sector, which is outside of the focus of this article, whilst the Länder DPAs regulate the private sector. In contrast, in Spain regional DPAs in Catalonia and the Basque country regulate those entities operating under their region's public law, whilst the Spanish federal DPA is responsible for regulation of all other private and public entities. In the German case, given that responses were received from both the German federal DPA and four Länder DPAs, it was decided to drop separate consideration of the federal DPA and notionally reallocate a portion of the former's budget to the four Länder jurisdictions pro-rated on the basis of their population size within Germany as of $2013 .^{69}$ Since the German federal DPA's response had indicated no enforcement action as regards new media, the enforcement response from each German Land DPA in effect also represented the combined DPA enforcement efforts specific to that geographic jurisdiction. In the case of Spain, given that no Spanish federal DPA response was received to sit alongside that of the Spanish Catalan DPA, it was considered best to drop the Spanish Catalonian jurisdiction from this part of the analysis as well as the

\footnotetext{
${ }^{66}$ In some cases, the Euro figure provided was only an approximate. Where an exact local currency figure was also set out, this was generally preferred. The only exception was Latvia as no Eurostat figure could be found for the required conversion.

${ }^{67}$ Eurostat Euro/Ecu exchange rates - monthly data «http://appsso.eurostat.ec.europa.eu/nui/show.do?dataset=ei_mfrt_m\&lang=en

${ }^{68}$ No issue arose in relation to Gibraltar since the regional DPA here is comprehensively responsible for regulating both the public and private sectors within this jurisdiction.

${ }^{69}$ Germany, Statisches Bundesamt Regional Statistics in Brief «http://www.destatis.de/EN/FactsFigures/CountriesRegions/RegionalStatistics/RegionalStatistics.htm».
} 
inter-jurisdictional investigations later in this article. ${ }^{70}$ Since the budget figures for all these jurisdictions were clearly strongly affected by the very divergent size of the residential population served by the various DPAs, ${ }^{71}$ these gross figures were additionally translated into per capita ones using population figures obtained from Eurostat, ${ }^{72}$ the Statisches Bundesamt ${ }^{73}$ and the Government of Gibraltar. ${ }^{74}$ Table Three below provides a cross-tabulation of reported DPA gross budgets (separated into a number of exponentially larger categories ${ }^{75}$ ) and per capita budgets (rounded to the nearest $€ 0.1$ with the exception of the highest category $(<€ 0.7)$ which comprises three outlier DPAs serving microjurisdictions ${ }^{76}$ ). Exact figures are set out in the appendix. From this, it was calculated that the average gross reported budget was approximately €3.4M, whilst the median per capita budget was $€ 0.33$.

\footnotetext{
${ }^{70}$ For completeness, the Spain Catalan DPA reported a budget of approximately $€ 2.8$ million whilst the German federal DPA reported one of $€ 8.5$ million

${ }^{71}$ Given the structure of data protection, DPAs are in theory responsible for supervising the processing of any personal data subject to their jurisdiction "whatever the nationality or residence of [the] natural persons" (recital 3, Directive 95/46). Given the nature of the internet, this could easily make a DPA even in a small jurisdiction responsible for data relating to hundreds of millions of individuals. In practice, however, DPAs have not applied this logic. For example, in its response to Google Spain, although acknowledging that "[u]nder EU law, everyone has the right to data protection" the Article 29 Working Party stated that "[i]n practice, DPAs will focus on claims where there is a clear link between the data subject and the EU, for instance where the data subject is a citizen or resident of an EU Member State". Article 29 Working Party Guidelines on the Implementation of the Court of Justice of the European Union Judgment on "Google Spain and Inc v Agencia Española de Protección de Datos (AEPD) and Mario Costeja González” C-131/12 (2014), 3 «http://ec.europa.eu/justice/data-protection/article-29/documentation/opinionrecommendation/files/2014/wp225_en.pdf».

${ }^{72}$ Eurostat Population on 1 January «http://ec.europa.eu/eurostat/tgm/table.do?language=en\&pcode=tps00001». ${ }^{73}$ Germany, Statisches Bundesamt, op. cit., n. 69.

${ }^{74}$ Government of Gibraltar Abstract of Statistics 2013 (2014) «https://www.gibraltar.gov.gi/new/images/stories/PDF/statistics/2014/Abstract_of_Statistics_2013.pdf ». ${ }^{75}$ The last of these categories was in practice necessarily capped at the value of the highest reported DPA budget $(€ 19.23 \mathrm{M})$.

${ }^{76}$ Namely, the Luxembourg, Gibraltar and Liechtenstein DPAs which had per capita reported budgets of $€ 2.98$, $€ 4.20$ and $€ 16.05$ respectively.
} 
Table Three: Reported Gross and Per Capita DPA Budgets

\begin{tabular}{|c|c|c|c|c|c|c|c|}
\hline $\begin{array}{l}\frac{\text { Gross }}{\text { Budget } \rightarrow} \\
\text { Per Capita } \\
\text { Budget } \downarrow\end{array}$ & $<€ 0.5 \mathrm{M}$ & $\begin{array}{l}\geq € 0.5 \mathrm{M} \text { to } \\
<€ 1.5 \mathrm{M}\end{array}$ & $\begin{array}{l}\geq € 1.5 \mathrm{M} \text { to } \\
<€ 3.5 \mathrm{M}\end{array}$ & $\begin{array}{l}\geq € 3.5 \mathrm{M} \text { to } \\
<€ 7.5 \mathrm{M}\end{array}$ & $\begin{array}{l}\geq € 7.5 \mathrm{M} \text { to } \\
<€ 15.5 \mathrm{M}\end{array}$ & $\begin{array}{l}\geq € 15.5 \text { (to } \\
<19.23 \mathrm{M})\end{array}$ & $\begin{array}{l}\text { Number } \\
\text { (approx. } \\
\% \text { ) }\end{array}$ \\
\hline$€ 0.1$ & & $\begin{array}{l}\text { Austria; } \\
\text { Slovakia }\end{array}$ & & Poland & Italy & & $4(14 \%)$ \\
\hline$€ 0.2$ & Latvia & Lithuania & $\begin{array}{l}\text { Greece; } \\
\text { Hungary; } \\
\text { Bulgaria }\end{array}$ & & & & $5(17 \%)$ \\
\hline$€ 0.3$ & $\begin{array}{l}\text { Cyprus; } \\
\text { Estonia }\end{array}$ & & $\begin{array}{l}\text { Portugal; } \\
\text { Finland }\end{array}$ & & & France; UK & $6(21 \%)$ \\
\hline$€ 0.4$ & & & $\begin{array}{l}\text { Germany } \\
\text { Rhineland- } \\
\text { Palatinate }\end{array}$ & & & & $1(3 \%)$ \\
\hline$€ 0.5$ & & Slovenia & Ireland & $\begin{array}{l}\text { Sweden; } \\
\text { Belgium }\end{array}$ & Netherlands & & $5(17 \%)$ \\
\hline$€ 0.6$ & & & $\begin{array}{l}\text { Germany } \\
\text { Schleswig- } \\
\text { Holstein }\end{array}$ & $\begin{array}{l}\text { Czech } \\
\text { Republic }\end{array}$ & & & $2(7 \%)$ \\
\hline$€ \mathbf{€ 0 . 7}$ & Malta & $\begin{array}{l}\text { Germany } \\
\text { Mecklenburg- } \\
\text { Vorpommern } \\
\end{array}$ & $\begin{array}{l}\text { Germany } \\
\text { Brandenburg }\end{array}$ & & & & $3(10 \%)$ \\
\hline$>€ 0.7$ & Gibraltar & Liechtenstein & Luxembourg & & & & $3(10 \%)$ \\
\hline $\begin{array}{l}\text { Number } \\
\text { (approx. \%) }\end{array}$ & $5(17 \%)$ & $6(21 \%)$ & $10(34 \%)$ & $4(14 \%)$ & $2(7 \%)$ & $2(7 \%)$ & \\
\hline
\end{tabular}

\section{ANALYSIS OF STANDARDIZED RETURNS}

The results of the survey, summarized in Table One above, clearly indicate that most DPAs have adopted an expansive approach to the interpretation of data protection even in the area of online media expression. Firstly, data protection was almost always seen to be applicable to all types of online media. Thus, across all the online media actor scenarios, an average of only $7 \%$ of DPA responses considered the activity in question to be exempt (category a/0), with a minimum of $0 \%$ responses in this category in the case of both the social networking site (example 5) and street mapping (example 7) through to a maximum of only $16 \%$ in the case of the individual social networker (example 4)). Secondly, notwithstanding its central role in the original legislative debate on the interface between data protection and public freedom of expression, DPAs also generally considered that the Article 9 special purposes derogation (category b/0.33) was not applicable to most forms of online media activity. Indeed, only as regards the newspaper archive (example 1) was this category the modal one selected. Moreover, as regards examples 3,6 and 7, which concerned the 
rating website, search engine and street mapping service respectively, no responses selected that category. Thirdly, a significant group of DPAs did indicate that an ad hoc balancing of default data protection provisions with freedom of expression (category c/0.67) would be necessary as regards the individual blogger, rating website and individual social networker (examples 2, 3 and 5). However, with the exception of the individual blogger, almost as many or more DPAs claimed that default data protection should simply apply in full (category $\mathrm{d} / 1$ ). Meanwhile, this latter most stringent perspective was supported by the clear majority of DPAs in the case of the social networking site, search engine and street mapping service (examples 5 - 7). This category was also the most selected one overall, a fact which helps explain the high average interpretation score of 0.75 , a figure which highlights the theoretically constrained understanding of freedom of expression by DPAs here. The stringent nature of the interpretative stance adopted may be linked to the symbolically central position data protection within European fundamental rights coupled with the role played these agencies as "guardian[s]"77 of this framework. A stressing of data protection's general importance may also help DPAs in their quest for better resourcing and "enhanced regulatory powers". ${ }^{78}$ In sum, the European data protection system appears to have substantially attained a harmonization of the interpretation of data protection at the theoretically equivalent and high level of protection set out in Directive 95/46. ${ }^{79}$

However, notwithstanding the increasing rhetorical focus on data protection as a fundamental right, the figures above on enforcement (Table Two), paint a starkly different picture regarding the practical reality of data protection as applied to online media expression. Firstly, the most common DPA position in relation to all seven online media actors was to report no enforcement whatsoever (category a/0); moreover, this was the majority position in relation to all but street mapping (example 7). Secondly, overall, only $16 \%$ of responses indicated that enforcement action had been taken place both in the context of information obtained without proper authorization from another data controller and in another context connected to publication (category d/1); moreover, even the case-specific high

\footnotetext{
${ }^{77}$ Commission v Germany, op. cit, n. 11 at [23].

${ }^{78}$ Newman, op. cit., n. 5, p. 190.

${ }^{79}$ Nevertheless, even here it should be noted that the survey results disclosed a range of standard deviations ranging from the very low figure of 0.09 in the case of street mapping services (example 7 ) to the fairly high value of 0.36 in the case of the individual on a social networking site (example 4). This suggests that a diversity even of basic interpretative stance remains present as regards the applicability of data protection to individuals online.
} 
here (which related to social networking sites (example 5)) was only $23 \%$. Thirdly, the overall average enforcement score registered was very low $(0.31)$, with the bottom score $(0.17)$ attributed to search engines (example 6) ${ }^{80}$ and the top (0.38) to street mapping services (example 7) ${ }^{81}$ Finally, a clear disparity of response across all the scenarios produced very high and stable standard deviations which at 0.39 averaged more than the overall enforcement score. ${ }^{82}$ These results contrast markedly with Epp's finding in the comparative case of the United States that strong enforcement mechanisms had emerged in those policy areas which had become infused with "rights-based aspirations" ${ }^{83}$

However, development in this case rested not a European-style regulatory system but rather on a "decentralized, court-centred system of oversight" ${ }^{\prime 84}$ epitomized by the private class action. ${ }^{85}$

The generally low level of enforcement in Europe may be linked to the resourcing of the DPAs, which remains very limited whether measured on the basis of either the gross or per capita budget figures detailed above. Personal information and its use is complex, ubiqutious and growing exponentially; ${ }^{86}$ moreover, many of the companies involved such as Facebook and Google have enormous financial clout. ${ }^{87}$ Given this, the reported average gross DPA budget of $€ 3.4 \mathrm{M}$ and the per capita funding level of around $€ 0.33$ hardly appears commensurate with the weighty and important

\footnotetext{
${ }^{80} \mathrm{It}$ is recognised that the particularly low figure here may reflect the fact that a number of DPAs were waiting for the Google Spain decision to be handed down before considering whether to take action (Google Spain, Google v Agencia Española de Protección de Datos, Mario Costeja González (C-131/12) EU:C:2014:317). ${ }^{81}$ Although, as specified above, it did not provide possible collect comprehensive data on enforcement activity through public available information readily available on DPA websites, the information which was collated also indicated very low levels of enforcement. Indeed, vis-à-vis all the examples other than street mapping services, clear evidence of enforcement action was found only in relation to a handful of the DPAs in each case. ${ }^{82}$ It may be hypothesized that, as regards the different online media actors, we should expect a significant and positive relationship between the average interpretation score and the average enforcement score. Correlative analysis does not support this, however, as the Spearman's rank is 0.09 with a two-tailed significance value of 0.848 .

${ }^{83}$ C. Epp, Making Rights Real: Activists, Bureaucrats, and the Creation of the Legalistic State (2010), p. 288 ${ }^{84}$ Id., p. 288.

${ }^{85}$ Of course, the United States has also refused to endorse the conception of data protection as a fundamental right, a reality which has led to increasing tension with Europe which reached a partial dénouement in Schrems v Data Protection Commissioner (C-518/07) EU:C:2016:650.

${ }^{86}$ Thus, Floridi cites evidence that "between 2006 and 2010 the global quantity of digital data will have increased more than six-fold, from 161 exabytes to 988 exabytes" (p. 6) arguing further that the resulting "infosphere is progressively absorbing any other space" (L. Floridi, Information: A Very Short Introduction (2010), p. 16).

${ }^{87}$ Google reported a 2013 turnover of $\$ 15.7 \mathrm{bn}$ whilst Facebook’s turnover was $\$ 7.87 \mathrm{bn}$ which, using average 2013 figures provided by Eurostat, translates into $€ 20.85 \mathrm{bn}$ and $€ 10.45 \mathrm{bn}$ respectively (see Google 'Google Inc Announces Fourth Quarter and Fiscal Year 2013 Results' (2014) «https://investor.google.com/earnings/2013/Q4_google_earnings.html»). D. Rusche 'Facebook posts record quarterly results and reports $\$ 1.5 \mathrm{bn}$ profit for 2013' (2014) Guardian Online «http://www.theguardian.com/technology/2014/jan/29/facebook-record-quarterly-results»).
} 
tasks regulators have allocated to them. Nevertheless, it is also clear that there are significant differences in DPA resourcing levels, with some DPAs being several times better funded than others, whether measured on a gross or per capita basis. Whether these or other contrasts can help explain the divergences in reported enforcement of data protection vis-à-vis the online media will be analysed in the next section.

\section{EXPLORING DIVERGENCES IN DPAS' REPORTED ENFORCEMENT ACTIVITY}

The survey results clearly indicated that reported enforcement vis-à-vis online media expression differed substantially between the DPAs. At the most basic level, it is possible to measure this simply by producing a count of the number of types of specified online media actor that each DPA reported it had taken at least some enforcement action against. A more detailed picture, which factors in the type of enforcement registered, is obtained by calculating an enforcement score for each DPA as an average of the categorical enforcement values it reported in relation to all seven online media actors. Table Four below orders DPAs according to their enforcement count and also details their enforcement score. Based on a similar justification to that outlined above as regards DPA resourcing, namely the essentially non-existent jurisdiction of both the German federal DPA and the Spanish Catalan DPA vis-à-vis the private sector as a result of the federal division of powers, these two agencies are excluded from this table and also from the rest of the analysis in this section. ${ }^{88}$ As can be seen, whilst approximately $10 \%$ of the DPAs reported enforcement action against all seven types of online media actor, almost a quarter indicated no enforcement whatsoever. The enforcement count figures also differed widely (from 0 to 0.81 ) and the relationship between the two variables was extremely strong. ${ }^{89}$

Table Four: DPA Reported Enforcement Against Specified Online Media Actors (n=29)

\footnotetext{
${ }^{88}$ For completeness, it should be noted that, whilst the German federal DPA reported no enforcement activity, the Spanish Catalan DPA did indicate that it had carried out enforcement in relation to a news archive and a blogger both as regards material obtained without proper authorization from another data controller and otherwise.

${ }^{89}$ The (non-parametric) Spearman's rank correlation is 0.964 with a two-tailed significance value of 0.00 .
} 


\begin{tabular}{|l|l|l|}
\hline $\begin{array}{l}\text { Enforcement } \\
\text { Count }\end{array}$ & Data Protection Authorities (DPAs) (Enforcement Score) & $\begin{array}{l}\text { Number } \\
\text { (approx. \%) }\end{array}$ \\
\hline Seven & Belgium (0.81), Finland (0.62), Hungary (0.67) & $3(10 \%)$ \\
\hline Six & Austria (0.57), Lithuania (0.76), Slovenia (0.72) & $3(10 \%)$ \\
\hline Five & Czech (0.62), Estonia (0.71), France (0.48), Latvia (0.38) & $4(14 \%)$ \\
\hline Four & German Schleswig-Holstein (0.57), Netherlands (0.57) & $2(7 \%)$ \\
\hline Three & Germany Rhineland-Palatinate (0.29), Italy (0.33), Luxembourg (0.24), Poland (0.14) & $4(14 \%)$ \\
\hline Two & Cyprus (0.19), Greece (0.29), Sweden (0.19) & $3(10 \%)$ \\
\hline One & Bulgaria (0.1), German Mecklenburg-Vorpommern (0.1), Portugal (0.1) & $3(10 \%)$ \\
\hline Zero & $\begin{array}{l}\text { German Brandenburg (0), Gibraltar (0), Ireland (0), Liechtenstein (0), Malta (0), } \\
\text { Slovakia (0), United Kingdom (0) }\end{array}$ & $7(24 \%)$ \\
\hline
\end{tabular}

Even aside from the federal jurisdictional issues which confront DPAs in Germany and Spain, there are a multitude of reasons why a DPA in one jurisdiction may take enforcement action against a particular type of online media actor whilst another DPA does not. For example, some actors may be present in one jurisdiction but not the other. Moreover, even if the actor is present in both, if its activity falls within article 9 special purposes as defined in national law then, notwithstanding the contrary steer in article 9 and recital 37 of Directive 95/46, a DPA may find that all possibility for it to engage in substantive enforcement has have been removed under local legislation. ${ }^{90}$ However, notwithstanding the potential validity of these rationales in specific contexts, they should not play a significant role in structuring global divergences between the DPAs. The online media actors included in the survey are all well-established and ubiquitous. Therefore, whilst a few of these actors (for example, street mapping services) may indeed not be present in a few EEA jurisdictions, the great majority (from news archives to bloggers to social networkers) are present in all of them. Moreover, given that, as explicated above, the great majority of DPAs explicitly consider the special purposes derogation to be inapplicable as regards most forms of online media activity, formal differences in the legal regulation or national scope of such purposes should also only exercise a marginal overall effect.

In contrast, we might credibly expect differences, firstly, in the level of financial resourcing of the DPAs and, secondly, in the stringency of their own interpretative stance to drive divergence in reported enforcement documented above. Turning first to resourcing, it can be hypothesized that the capacity of a DPA to undertake various types of enforcement action against online media depends

\footnotetext{
${ }^{90}$ For an analysis of the very significant substantive divergences here see D. Erdos, ““'European Data Protection and Media Expression: Fundamentally Off Balance" (2016) 65 International and Comparative Law Quarterly 139.
} 
both on the overall level of its funding and on how well it is funded on a per capita basis. Thus, a very small DPA, even if well-funded on a per capita/head of resident population basis, may still not be able to mount a credible challenge to a large social networking site or search engine. Similarly, a DPA with a sizable gross budget but minimal per capita resources may be so over-burdened by a wide range of individual data concerns that it is unable to engage in the kind of complex and strategic action often required in the online media context. To test this hypothesis, a combined measure of DPA financial resourcing was created based on both the gross and per capita budget figures. ${ }^{91}$ This measure was constructed by transposing both sets of data on to a linear scale where 1 represented the resources available to the DPA best funded on the relevant basis and all the other figures were expressed in terms of a proportion of this. For each DPA, an average was then taken of both of these two transposed scores (see the appendix for the combined average scores). Reflecting the nonparametric nature of the data, Table Five overleaf details a Spearman's rank correlation between this combined budget measure and both DPAs' online media actor enforcement count and their online media average data protection enforcement score. The same correlations are also presented using both the gross and per capita budget figures. As can be seen, as regards both the combined and the per capita budget measures, the results are not only insignificant but also opposite to the expected direction. ${ }^{92}$ Meanwhile, although the results for the gross budget measure are in the right direction, the correlations are not only extremely small but manifestly insignificant. Although it is recognised that these budget figures focus on one period in time, whilst the enforcement figures relate to a longer time period, the complete lack of any significant positive relationship suggests that (notwithstanding an overwhelming regulatory consensus that online media expression generally strongly engages data protection) better resourcing of DPAs does not by itself lead to extensive enforcement activity being undertaken against new media actors.

\footnotetext{
${ }^{91}$ As previously noted above, in the case of the German Länder DPAs all these measures had been adjusted in order to reallocate a portion of the national German DPA budget to them pro-rated on the basis of their population size within Germany, thus creating a measure of the resources available in the relevant geographical jurisdiction for regulating data protection in both the private and public sector. Since the German federal DPA had reported no enforcement activity as regards the new media, the response from each German Länder DPA in effect also represented the combined enforcement efforts specific to that particular jurisdiction.

92 This counterintuitive result may have been influenced by the fact that DPAs serving micro jurisdictions generally have very disproportionately large per capita budgets.
} 
In order to investigate a possible relationship between the stringency of a DPA's

interpretative stance and its enforcement track-record, it was necessary to compute an interpretation

score for each DPA as an average of the interpretation values registered for all seven online media

actors. Creation of such an average was complicated by the fact that a large proportion of DPAs

provided an answer here in free-text form. In order to accommodate this, quasi-standardized answers

were imputed from an analysis of this free-text answer (or in two cases where the free-text answer had no substantive content, from the answer provided by the overwhelming majority of the other DPAs). ${ }^{93}$

This process allowed for an interpretation score to be calculated for all but two of the responding

DPAs. ${ }^{94}$ Table Five below also provides details of a Spearman rank correlation run between these

interpretation scores, the DPAs' enforcement count and their enforcement score. As can be seen, in

clear contrast to the financial resourcing figures, there is evidence of a strongly positive and

significant correlation between a DPA's interpretative score and its likelihood of having reported

undertaking various form of enforcement action in this area. In other words, those DPAs with an

interpretative stance even more stringent than the generally expansive approach adopted by the vast of majority of EU DPAs were likely to have adopted an active enforcement stance as regards online media expression, whilst those with a less stringent approach than the average were very unlikely to have done so. ${ }^{95}$

\footnotetext{
${ }^{93}$ In the case of the Slovenian DPA, the free-text responses were found to relate equally to categories a/ 0 and $\mathrm{d} / 1$. As a result, an average was taken of these, resulting in a unique score of 0.5. A full analysis of these freetext responses and the process of quasi-standard answer imputation is provided in D. Erdos, "Data Protection Confronts Freedom of Expression on the 'New Media' Internet: The Stance of European Regulatory Authorities" (2015) 40 European Law Review 531. The results used are also set out in the appendix to this article.

${ }^{94}$ The UK DPA did not provide any answer to the interpretative questions and, therefore, obviously could not be included. The Netherlands DPA only provided an answer to two out of the seven online media examples and therefore similarly failed to provide enough data to impute a comprehensive score.

${ }^{95}$ Spearman's rank correlations were also performed using street mapping enforcement data gathered from DPA websites. This confirmed a strong association between such enforcement and the DPA's interpretation score (coefficient0.489, significance: 0.015 ) and the lack of any association of two-tailed significance between enforcement and either the combined and per capita budget measures (coefficients 0.316 and -0.234 and significance 0.124 and 0.260 respectively). At the same time, it also suggested a clearly positive association between this enforcement action and the gross budget measure (coefficient: 0.524; significance: 0.007). This last result, however, needs to be treated with great circumspection since it is apparent that Google Street View is not present in many of the smaller jurisdictions (which naturally have lower gross budgets) such as Cyprus, Liechtenstein and Malta. These DPAs have, therefore, not had significant opportunities to enforce in this area, a fact which explains why they all reported no enforcement action.
} 
Table Five: Spearman Rank Correlations (and Two-Tailed Significance Tests) between DPA Enforcement, Resourcing and Interpretative Measures

\begin{tabular}{|l|l|l|}
\hline & Enforcement Count & Enforcement Score \\
\hline DPA Resourcing (n=29) & & \\
\hline Combined Budget Measure & $\begin{array}{l}\text { Coefficient: }-0.169 \\
\text { Significance: } 0.380\end{array}$ & $\begin{array}{l}\text { Coefficient: }-0.176 \\
\text { Significance: } 0.362\end{array}$ \\
\hline Gross Budget Measure & $\begin{array}{l}\text { Coefficient: 0.108 } \\
\text { Significance: } 0.576\end{array}$ & $\begin{array}{l}\text { Coefficient: } 0.100 \\
\text { Significance: } 0.606\end{array}$ \\
\hline Per Capita Budget Measure & $\begin{array}{l}\text { Coefficient: } 0.307 \\
\text { Significance: } 0.105\end{array}$ & $\begin{array}{l}\text { Coefficient: }-0.247 \\
\text { Significance: } 0.197\end{array}$ \\
\hline DPA Interpretative Stance (n=27) & & \\
\hline Interpretation Score & $\begin{array}{l}\text { Coefficient: } 0.442^{*} \\
\text { Significance: } 0.021\end{array}$ & $\begin{array}{l}\text { Coefficient: } 0.489^{* *} \\
\text { Significance: } 0.010\end{array}$ \\
\hline
\end{tabular}

$*$ = significant at 0.05 level.

$* *$ significant at the 0.01 level

Finally, it may be argued that, given that the survey explored enforcement since the transposition of Directive 95/46, it might be appropriate to augment both the enforcement count and the enforcement score of those DPAs operating in Eastern Europe jurisdictions together with Cyprus and Malta which only became members of the EU and subject to the Directive long after 24 October 1998, the date when transposition was required within the EU. ${ }^{96}$ Such an augmentation can be achieved by adjusting these figures to reflect the fact that, whilst the survey generally probed some $14 \frac{1}{2}$ years of potential enforcement, Bulgaria only joined the EU on 1 May 2005 and therefore 'lost' approximately 8 years of potential enforcement (55\% of the total period), whilst the other jurisdictions joined on 1 May 2005 and therefore similarly 'lost' approximately 51/2 years (38\% of the total period). ${ }^{97}$ Such an adjustment, however, makes no significant difference to the results reported above. The correlations with DPA financial resourcing remain not only insignificant but often in the unexpected direction. In contrast, the correlations between the average data protection interpretation

\footnotetext{
${ }^{96}$ Directive 95/46, art. 32 (1). As an EU-associated EEA state, Liechtenstein only became subject to the Directive on 26 June 1999 (see op. cit., n. 8). However, this seven-month gap was considered too small to have a significant effect on these results and so no adjustment was made here.

${ }^{97}$ In sum, both Bulgarian DPA's enforcement count and its enforcement score was multiplied by 1 plus 0.55 (representing the 'lost' years). The scores of the other Eastern European jurisdictions, together with that of Cyprus and Malta, were similarly multiplied by 1 plus 0.38 .
} 
score and both the adjusted enforcement count ${ }^{98}$ and the adjusted enforcement score ${ }^{99}$ remain both strong and significant.

In sum, although the great majority of DPAs have coalesced on a theoretically onerous interpretative stance vis-à-vis online media expression, most have failed to engage in extensive enforcement in this area. Whilst the generally low level of reported enforcement may be linked to the limited resources of these agencies, the serious divergences between them appear related not to this factor but rather to continued disparity in the severity of their interpretative stance. Moving from a symbolically onerous interpretation into active enforcement in an area such as online media expression may require taking on powerful interests and result in negative publicity. To take the most high profile example, the action by the Spanish DPA to secure a right of erasure on search engines which led to the landmark Google Spain decision required not only confronting an internet behemoth but also publicity decrying the authority's stance as "akin to marching into a library and forcing it to pulp books". ${ }^{100}$ In general, it appears that only DPAs with a particularly strong ideological commitment to data protection are likely to prove willing to take on such risks across the online media space. A focus on the often largely paper-based system of "networked governance"101 achieved within the Article 29 Working Party may, therefore, overemphasise the level of convergence and effectiveness which has practically been achieved within European data protection. This is problematic since such qualities are clearly integral to a well-functioning regime.

\section{PROSPECTS FOR REFORM}

After several years of negotiation, the EU has now agreed a new General Data Protection Regulation which will replace the existing Directive in 2018. ${ }^{102}$ Substantively, this Regulation

\footnotetext{
98 The Spearman's rho became 0.423 with a two-tailed significance value of 0.028 .

${ }^{99}$ The Spearman's rho became 0.481 with a two-tailed significance value of 0.011 .

${ }^{100}$ Index on Censorship Index blasts EU court ruling on "right to be forgotten" (2014) «https://www.indexoncensorship.org/2014/05/index-blasts-eu-court-ruling-right-forgotten».

${ }^{101}$ Newman, op. cit., n. 5, p 182.

102 Regulation (EU) 2016/679 of the European Parliament and of the Council of 27 April 2016 on the protection of natural persons with regard to the processing of personal data and on the free movement of such data, and repealing Directive 95/46/EC (General Data Protection Regulation), art. 99 (2).
} 
significantly augments the already stringent European approach including through an expanded list of data principles, ${ }^{103}$ much more onerous requirements to ensure transparency for data subjects ${ }^{104}$ and far more rule-based discipline mechanisms such as detailed requirements to notify many types of data breaches to a DPA and sometimes even data subjects themselves. ${ }^{105}$ This new instrument also places considerably greater formal emphasis on enforcement and harmonization. Thus, at least outside the special expressive purposes the pan-European governance of which remains largely unaltered, ${ }^{106}$ DPAs are to be empowered to issue administrative fines for breaches of most aspects of the regime of up to either $€ 10 \mathrm{M}$ or $€ 20 \mathrm{M}$ or in the case of commercial undertakings up to either $2 \%$ or $4 \%$ of annual worldwide turnover if this is higher. ${ }^{107}$ It is also stated that each DPA must be provided with the "human, technical and financial resources, premises and infrastructure necessary for the effective performance of its tasks and exercise of its powers". ${ }^{108}$ As regards cross-border processing, ${ }^{109}$ the Regulation sets out rules for ensuring that one lead DPA be appointed to coordinate all matters relating to the enforcement of the law. ${ }^{110}$ At the same time, a consistency mechanism is established whereby other DPAs or the Commission may require that the European Data Protection Board (a reconstituted and greatly enhanced continuation of the Article 29 Working Party) issue an Opinion which the lead DPA must either follow ${ }^{111}$ or face an ultimately binding Decision being issued against it by the same body. ${ }^{112}$ The Regulation also clarifies that the right to individual compensation incorporates a notion of joint and several liability, that it relates to both material and immaterial damage and that, as regards private controllers, data subjects may bring proceedings wherever they have their habitual residence. ${ }^{113}$ Finally, whilst many provisions will still allow for derogations

\footnotetext{
${ }^{103}$ Regulation 2016/679, art. 5.

${ }^{104}$ Regulation 2016/679, arts. 12-15.

${ }^{105}$ Id., arts. 33-34.

${ }^{106}$ Id., art. 85 (2).

${ }^{107}$ Id., art. 83. Due to the peculiarities of their legal system, in Denmark and Estonia special procedures will apply such that fines will be initiated by a DPA but imposed by the courts. See Id., recital 151 and art. 79 (9).

${ }^{108}$ Id., art. 52 (4).

${ }^{109}$ Id., art. 4 (23).

${ }^{110} \mathrm{Id}$. , arts 4 (16) and 56.

${ }^{111}$ Id., art. 64.

${ }^{112}$ Id., art. 65.

${ }^{113}$ Id., arts 82 and 79 (2).
} 
specific to each Member State, ${ }^{114}$ the directly applicable nature of a regulation means that (potentially divergent) transposition at national level will not in general be necessary.

Despite this, experience under the existing law may lead one to question whether the Regulation will in practice prove adequate to the challenges elucidated above. Even under Directive 95/46, Member States are required to adopt measures and sanctions "to ensure the full implementation" 115 of data protection and the great majority have instituted not just wide-ranging administrative sanctions but also criminal provisions (which often carry a maximum penalty of several years imprisonment). ${ }^{116}$ As regards private compensation, the Directive is already clear that a controller will be presumed liable unless "he proves that he is not responsible for the event giving rise to the damage". ${ }^{117}$ The Directive also not only sets out the wide-ranging obligations of DPAs to hear claims from data subjects, undertake checks on the legality of processing and monitor the application of the law ${ }^{118}$ but further states both that these independent DPAs "must have the necessary means to perform their duties"119 and that they "shall cooperate within one another to the extent necessary for the performance of their duties". ${ }^{120}$ In principle, these formalities have been reinforced by Court of Justice jurisprudence which has stressed inter alia that such provisions must be interpreted purposively "to ensure the effectiveness and reliability of the supervision of compliance" with data protection. ${ }^{121}$ However, such strictures have not prevented the emergence of the very partial and fissiparous enforcement reality as elaborated in this article. Such an outcome may instead be related, in a general sense, to a considerable mismatch between Europe's stringent data protection standards and the very limited resources of the DPAs and, more specifically, to a culture within a large number of DPAs where "enforcement actions [especially in controversial areas] have a rather low priority". ${ }^{122}$

\footnotetext{
${ }^{114}$ As well as art. 85 noted above see especially art. 23 (restrictions) and art. 9(2)(6) (derogations from the ban on processing sensitive or special categories of data).

115 Directive 95/46, art. 24.

${ }^{116}$ European Union, Agency for Fundamental Rights, op. cit., n. 9.

${ }^{117}$ Directive 95/46, art. 23 (2).

${ }^{118}$ Id., art. 28.

${ }^{119}$ Id., recital 63.

${ }^{120}$ Id., art. 28 (6).

${ }^{121}$ Commission v Germany, op. cit., n. 11 at [41].

${ }^{122}$ European Commission, 'First Report on the Implementation of the Data Protection Directive (95/46/EC)'

(20013) (COM (2003) 265 final), 12.
} 
Reflecting these experiences back on to the text of the Regulation, it is clear that even the new wording on the resourcing of DPAs remains vague, a reality which, at least initially, may result in only a limited change in national practice. Moreover, whilst individual private remedies are somewhat enhanced, the Regulation stops short of mandating representative class action (absent the individual mandate of each data subject). ${ }^{123}$ On the other hand, compared to the rather general provisions in the Directive, the presence in the Regulation of both new DPA powers to fine up to extremely high levels and a detailed consistency mechanism which can be triggered in cross-border situations, could shift practice over time towards both greater and more harmonized enforcement. Nevertheless, the latter mechanism may prove so cumbersome and burdensome to operate that, aside from particularly large-scale and high-profile areas, considerable discretion will in practice be retained in hands of local DPAs. Thus, absent urgency, the Board may take up to eight weeks (extendable in complex cases by a further six) even to issue an initial Opinion, ${ }^{124}$ the local lead DPA will then have two weeks to respond ${ }^{125}$ and a further month (potentially extendable by another month) will be allowed for the Board to issue, by a two-thirds majority, any necessary binding Decision (art $65(2))^{126}$ which the lead DPA will have a further month to start implementing. ${ }^{127}$ Moreover, especially given that the resourcing needs of the central Board are not explicitly addressed in the Regulation, ${ }^{128}$ it is far from clear that this body will have the capacity to administer this mechanism on a large scale even if called to do so. Indeed, it has been argued that ensuring true effectiveness here "seems to presuppose some kind of EU data police who are active in all countries - something which is only conceivable far into the future". ${ }^{129}$ Finally, in responding at a substantive level with "more law, and specifically more-of-the-same law", the Regulation risks exacerbating rather than

\footnotetext{
${ }^{123}$ See Regulation 2016/679, art. 80.

${ }^{124}$ Id., art. 64 (3).

${ }^{125}$ Id., art. 64 (7).

${ }^{126} \mathrm{Id}$., at. 65 (2). If such a majority can still not be obtained even after the expiry of such a period, then the Board must adopt a decision by a simple majority within a further two week period (Id., art. 65 (3)).

${ }^{127}$ Id., art. 65 (6).

${ }^{128}$ The only relevant provision is article 75 (1) which simply states that the European Data Protection Supervisor will provide a secretariat for the Board.

${ }^{129}$ P. Blume, 'The myths pertaining to the proposed General Data Protection Regulation' (2014) 4 International

Data Privacy Law 269, 272.
} 
ameliorating the "regulatory disconnection between data protection law and data-processing practice". ${ }^{130}$

\section{CONCLUSIONS}

Principally as a result of Directive 95/46 and more recently through its recognition in both the EU Charter and treaties, Europe has committed itself to far-reaching data protection laws supervised by statutory regulators who cooperate within the Article 29 Working Party system. This framework has potentially serious implications for the increasingly ubiquitous phenomena of online media publication. In light of this, a comprehensive survey of EEA DPAs explored the interface between European data protection and the publication activities of seven ubiquitous types of online media actor. This survey demonstrated that these DPAs overwhelmingly consider data protection norms to be strongly engaged by online media expression, thereby concomitantly adopting a generally constrained understanding of freedom of expression. In contrast to this common stringent interpretative stance, enforcement has been both limited and uneven. Whilst the generally low level of enforcement may be related to a severe disparity between the stringency of the law and the meagre financial resources of these agencies, divergences between appear related rather to continuing discrepancies in their interpretative stance. In sum, only DPAs with a particularly stringent interpretative stance are likely to have engaged in extensive enforcement activity.

The theoretically stringent interpretative stance of DPAs may be linked to centrality of data protection within the maturing area of European fundamental rights coupled with their role both nationally and in pan-European forums as the guardians of this framework. ${ }^{131}$ Nevertheless, as the Google Spain decision epitomised, moving beyond such theory into active enforcement often requires taking on powerful interests and exposure to negative publicity. Only those DPAs with a particularly strong ideological commitment to data protection appear willing to that those risks. A focus on pan-

${ }^{130}$ B. Koops, 'The Trouble with European Data Protection Law' (2014) 3 International Data Privacy Law 250, 256.

${ }^{131}$ G. Fuster, The Emergence of Personal Data Protection as a Fundamental Right of the EU (2014); O. Lynskey, 'Deconstructing Data Protection: The "Added-Value" of a Right to Data Protection in the EU Legal Order” (2014) 63 International and Comparative Law Quarterly 569. 
European processes of 'networked governance' within the Working Party has tended to obscure the resulting lack of practical effectiveness and equivalence within this regulatory regime.

Whilst the new General Data Protection Regulation is predicated on an acknowledgement of some of these deficiencies, questions remain as to whether it will in practice adequately confront these challenges. To be properly effective, it is essential that Member States ensure both that their local DPAs are resourced appropriately and that the European Data Protection Board is given the funding and institutional support necessary to perform its complex new enforcement functions. Finally, more work must be done to develop common legal interpretations which, whilst faithful to the protective ambitions of the law, also both take fully in to account other competing rights and link effectively to a credible enforcement strategy. Although such outcomes will likely prove difficult to achieve, anything less will fail to provide Europe with the robust, legally certain and effective data protection regime which it claims to value so highly. 
Appendix: Quantitative EEA DPA Data on Interpretation (Int.), Enforcement (Enf.) and Resourcing

\begin{tabular}{|c|c|c|c|c|c|c|c|c|c|c|c|c|c|c|c|c|c|c|c|c|c|}
\hline \multirow{2}{*}{$\begin{array}{c}\text { EEA DPA } \\
\text { Geographic } \\
\text { Jurisdiction }\end{array}$} & \multicolumn{2}{|c|}{$\begin{array}{c}\text { (1) } \\
\text { Newspaper } \\
\text { Archive }\end{array}$} & \multicolumn{2}{|c|}{$\begin{array}{c}(2) \\
\text { Individual } \\
\text { Blogger }\end{array}$} & \multicolumn{2}{|c|}{$\begin{array}{c}\text { (3) } \\
\text { Internet } \\
\text { Rating } \\
\text { Website } \\
\end{array}$} & \multicolumn{2}{|c|}{$\begin{array}{c}(4) \\
\text { Individual on } \\
\text { SNS } \\
\end{array}$} & \multicolumn{2}{|c|}{$\begin{array}{c}(5) \\
\text { Social } \\
\text { Networking } \\
\text { Site (SNS) } \\
\end{array}$} & \multicolumn{2}{|c|}{$\begin{array}{c}\text { (6) } \\
\text { Internet } \\
\text { Search } \\
\text { Engine } \\
\end{array}$} & \multicolumn{2}{|c|}{$\begin{array}{c}(7) \\
\text { Street } \\
\text { Mapping } \\
\text { Service } \\
\end{array}$} & \multicolumn{2}{|c|}{$\begin{array}{c}\text { Average } \\
\text { Scores }\end{array}$} & \multirow{2}{*}{$\begin{array}{l}\text { Enf. } \\
\text { Count }\end{array}$} & \multirow{2}{*}{$\begin{array}{c}\text { DPA } \\
\text { Website } \\
\text { Data On } \\
\text { Street } \\
\text { Mapping } \\
\text { Service } \\
\text { Enf. }\end{array}$} & \multicolumn{3}{|c|}{ Annual Budget } \\
\hline & Int. & Enf. & Int. & Enf. & Int. & Enf. & Int. & Enf. & Int. & Enf. & Int. & Enf. & Int. & Enf. & Int. & Enf. & & & $\begin{array}{c}\text { Gross } \\
€ M\end{array}$ & \begin{tabular}{|c|} 
Per \\
Capita \\
$€$ \\
\end{tabular} & $\begin{array}{c}\text { Combined } \\
\text { Scale }\end{array}$ \\
\hline Austria & $\underline{0.33}$ & 0 & $\underline{0.67}$ & 0.67 & 1 & 0.67 & 1 & 0.67 & 1 & 0.67 & 1 & 0.67 & 1 & 0.67 & 0.86 & 0.57 & 6 & 1 & 1.20 & 0.14 & 0.04 \\
\hline Belgium & 0.67 & 0.67 & 0.33 & 0.67 & 1 & 0.67 & 1 & 1 & 1 & 1 & 0.67 & 0.67 & 1 & 1 & 0.81 & 0.81 & 7 & 1 & 5.80 & 0.52 & 0.17 \\
\hline Bulgaria & 0.33 & 0 & 0 & 0 & 1 & 0 & 0 & 0.67 & 1 & 0 & 1 & 0 & 1 & 0 & 0.62 & 0.10 & 1 & 0 & $(1.51)$ & 0.21 & 0.05 \\
\hline Cyprus & 1 & 0.67 & 1 & 0.67 & 1 & 0 & 1 & 0 & 1 & 0 & 0.67 & 0 & 1 & 0 & 0.95 & 0.19 & 2 & 0 & 0.26 & 0.30 & 0.02 \\
\hline Czech Republic & 0.67 & 0 & 0.67 & 1 & 1 & 0.67 & 1 & 1 & 1 & 1 & (1) & 0 & 1 & 0.67 & 0.90 & 0.62 & 5 & 0.67 & 6.30 & 0.60 & 0.18 \\
\hline Estonia & 0.33 & 1 & 0.33 & 1 & 1 & 1 & 1 & 1 & 1 & 1 & 1 & 0 & 1 & 0 & 0.81 & 0.71 & 5 & 0 & 0.38 & 0.29 & 0.02 \\
\hline Finland & 0 & 0.33 & 0.33 & 1 & 0.67 & 1 & $\underline{0}$ & 0.33 & 1 & 1 & 1 & 0.33 & 1 & 0.33 & 0.57 & 0.62 & 7 & 0.67 & 1.80 & 0.33 & 0.06 \\
\hline France & 0.33 & 0.33 & 0.67 & 0 & 1 & 0.67 & 1 & 0 & 1 & 0.67 & 1 & 0.67 & 1 & 1 & 0.86 & 0.48 & 5 & 1 & 17.2 & 0.26 & 0.46 \\
\hline $\begin{array}{l}\text { Germany } \\
\text { Federal } \\
\end{array}$ & 0.33 & {$[0]$} & 0.67 & {$[0]$} & 0.67 & {$[0]$} & 0.67 & {$[0]$} & 0.67 & {$[0]$} & 1 & {$[0]$} & 1 & {$[0]$} & 0.71 & - & - & - & - & - & - \\
\hline $\begin{array}{l}\text { Germany } \\
\text { Brandenburg }\end{array}$ & 0.33 & 0 & 0.33 & 0 & 0.67 & 0 & 0.33 & 0 & 0.33 & 0 & 1 & 0 & 1 & 0 & 0.57 & 0 & 0 & - & 1.86 & 0.65 & 0.07 \\
\hline $\begin{array}{l}\text { Germany } \\
\text { Mecklenburg- } \\
\text { Vorpommern } \\
\end{array}$ & 0.33 & 0 & 0.67 & 0 & 0 & 0 & 1 & 0.67 & 1 & 0 & 1 & 0 & 1 & 0 & 0.71 & 0.10 & 1 & - & 1.27 & 0.69 & 0.05 \\
\hline $\begin{array}{l}\text { Germany } \\
\text { Rhineland- } \\
\text { Palatinate } \\
\end{array}$ & $\underline{0}$ & 0 & $\underline{0.33}$ & 0.67 & 0.67 & 0 & 0.67 & 0 & $\underline{0.67}$ & 0.67 & 1 & 0 & 1 & 0.67 & 0.62 & 0.29 & 3 & - & 1.92 & 0.38 & 0.06 \\
\hline $\begin{array}{l}\text { Germany } \\
\text { Schleswig- } \\
\text { Holstein } \\
\end{array}$ & 0.33 & 0 & 0.67 & 0.67 & 0.67 & 0 & 1 & 0.67 & 1 & 1 & 1 & 1 & 1 & 0.67 & 0.81 & 0.57 & 4 & - & 2.00 & 0.60 & 0.07 \\
\hline Gibraltar & 1 & 0 & 0 & 0 & 1 & 0 & 0 & 0 & 1 & 0 & 1 & 0 & 1 & 0 & 0.71 & 0 & 0 & 0 & $(0.15)$ & 4.95 & 0.16 \\
\hline Greece & 0.67 & 1 & 0.67 & 0 & 0.67 & 0 & 0.67 & 0 & 0.67 & 0 & 1 & 0 & 1 & 1 & 0.76 & 0.29 & 2 & 0.67 & 1.82 & 0.17 & 0.05 \\
\hline
\end{tabular}




\begin{tabular}{|c|c|c|c|c|c|c|c|c|c|c|c|c|c|c|c|c|c|c|c|c|c|}
\hline \multirow[t]{2}{*}{ EEA DPA } & \multicolumn{2}{|c|}{$\begin{array}{c}(1) \\
\text { Newspaper } \\
\text { Archive } \\
\end{array}$} & \multicolumn{2}{|c|}{$\begin{array}{c}(2) \\
\text { Individual } \\
\text { Blogger }\end{array}$} & \multicolumn{2}{|c|}{$\begin{array}{c}(3) \\
\text { Internet } \\
\text { Rating } \\
\text { Website }\end{array}$} & \multicolumn{2}{|c|}{$\begin{array}{c}(4) \\
\text { Individual } \\
\text { on SNS } \\
\end{array}$} & \multicolumn{2}{|c|}{$\begin{array}{c}(5) \\
\text { Social } \\
\text { Networking } \\
\text { Site (SNS) } \\
\end{array}$} & \multicolumn{2}{|c|}{$\begin{array}{c}\text { (6) } \\
\text { Internet } \\
\text { Search } \\
\text { Engine } \\
\end{array}$} & \multicolumn{2}{|c|}{$\begin{array}{c}(7) \\
\text { Street } \\
\text { Mapping } \\
\text { Service }\end{array}$} & \multicolumn{2}{|c|}{$\begin{array}{c}\text { Average } \\
\text { Scores }\end{array}$} & \multirow{2}{*}{$\begin{array}{c}\text { Enf. } \\
\text { Count }\end{array}$} & \multirow{2}{*}{$\begin{array}{c}\text { DPA } \\
\text { Website } \\
\text { Data On } \\
\text { Street } \\
\text { Mapping } \\
\text { Service } \\
\text { Enf. }\end{array}$} & \multicolumn{3}{|c|}{ Annual Budget } \\
\hline & Int. & Enf. & Int. & Enf. & Int. & Enf. & Int. & Enf. & Int. & Enf. & Int. & Enf. & Int. & Enf. & Int. & Enf. & & & $\begin{array}{c}\text { Gross } \\
€ M\end{array}$ & $\begin{array}{c}\text { Per } \\
\text { Capita } \\
€ \\
\end{array}$ & $\begin{array}{c}\text { Combined } \\
\text { Scale }\end{array}$ \\
\hline Hungary & 0.33 & 0.67 & 0.67 & 0.67 & 0.67 & 0.67 & 1 & 0.67 & 1 & 0.67 & 1 & 0.67 & 1 & 0.67 & 0.81 & 0.67 & 7 & 0.67 & $(1.61)$ & 0.16 & 0.05 \\
\hline Ireland & 0 & 0 & 0.67 & 0 & 0.67 & 0 & 0.67 & 0 & 0.67 & 0 & 0 & 0 & 0.67 & 0 & 0.48 & 0 & 0 & 0 & 2.20 & 0.48 & 0.07 \\
\hline Italy & 0.67 & 1 & 0.33 & 0.67 & 0.67 & 0 & 0.67 & 0 & 0.67 & 0 & 1 & 0 & 1 & 0.67 & 0.71 & 0.33 & 3 & 1 & $(8.50)$ & 0.14 & 0.23 \\
\hline Latvia & 0.33 & 0.67 & 0.67 & 0.33 & 0.67 & 0 & 1 & 0.33 & 0.67 & 0.67 & 0.67 & 0 & 0.67 & 0.67 & 0.67 & 0.38 & 5 & 0 & 0.39 & 0.19 & 0.02 \\
\hline Liechtenstein & 0.67 & 0 & 0.67 & 0 & 0.67 & 0 & 0.67 & 0 & $\underline{0}$ & 0 & 1 & 0 & 1 & 0 & 0.67 & 0 & 0 & 0 & 0.60 & 16.17 & 0.52 \\
\hline Lithuania & 0.67 & 1 & 0.67 & 1 & 0.67 & 1 & 0.67 & 1 & 0.67 & 1 & 1 & 0.33 & 1 & 0 & 0.76 & 0.76 & 6 & 0.67 & 0.55 & 0.19 & 0.02 \\
\hline Luxembourg & 0.67 & 0.33 & 0.67 & 0 & 1 & 0 & 1 & 0.67 & 1 & 0 & 1 & 0 & 1 & 0.67 & 0.90 & 0.24 & 3 & 1 & 1.60 & 2.98 & 0.13 \\
\hline Malta & 0.33 & 0 & 0.33 & 0 & 1 & 0 & 0 & 0 & 1 & 0 & 1 & 0 & 1 & 0 & 0.67 & 0 & 0 & 0 & 0.28 & 0.65 & 0.03 \\
\hline Netherlands & & 0 & & 0 & 1 & 1 & & 0 & & 1 & & 1 & 1 & 1 & & 0.57 & 4 & 0.33 & 7.50 & 0.45 & 0.21 \\
\hline Poland & 0.33 & 0 & 0.67 & 0 & 0.67 & 0.33 & $\underline{0}$ & 0 & 1 & 0.33 & $\underline{1}$ & 0 & 1 & 0.33 & 0.67 & 0.14 & 3 & 0.67 & (3.57) & 0.09 & 0.10 \\
\hline Portugal & $\underline{0.67}$ & 0 & 0.67 & 0 & 0.67 & 0 & 1 & 0 & 1 & 0 & 1 & 0 & 1 & 0.67 & 0.86 & 0.10 & 1 & 0.67 & 2.70 & 0.26 & 0.08 \\
\hline Slovakia & 0.33 & 0 & 0 & 0 & 1 & 0 & $\underline{0}$ & 0 & 1 & 0 & 0 & 0 & 1 & 0 & 0.48 & 0 & 0 & 0 & 0.66 & 0.12 & 0.02 \\
\hline Slovenia & $\underline{0.50}$ & 1 & $\underline{0.50}$ & 1 & 1 & 0.67 & 0 & 0.67 & 1 & 0.67 & 1 & 0 & 1 & 1 & 0.71 & 0.71 & 6 & 0.67 & 0.93 & 0.45 & 0.04 \\
\hline $\begin{array}{l}\text { Spain - } \\
\text { Catalonia } \\
\end{array}$ & 0.67 & [1] & 0.67 & [1] & 0.67 & {$[0]$} & 0.67 & {$[0]$} & 1 & {$[0]$} & 1 & {$[0]$} & 1 & {$[0]$} & 0.81 & - & - & 0 & - & - & - \\
\hline Sweden & 0 & 0 & $\underline{0.33}$ & 0.67 & 1 & 0.67 & $\underline{0.67}$ & 0 & $\underline{0.67}$ & 0 & $\underline{0}$ & 0 & $\underline{0.67}$ & 0 & 0.48 & 0.19 & 2 & 0 & (4.92) & 0.52 & 0.14 \\
\hline UK & - & 0 & - & 0 & - & 0 & - & 0 & - & 0 & - & 0 & - & 0 & - & 0 & 0 & 0.33 & (19.23) & 0.30 & 0.51 \\
\hline
\end{tabular}

Appendix Notes: Values which are underlined are imputed; those which are italicized are based on DPA estimates and those in brackets have been converted to Euros from a local currency (which was preferred to any Euro estimate provided with the exception of Latvia where no Eurostat figure could be found for the required conversion from Lats). The figures in square brackets from the German national and Spanish Catalan DPAs are excluded from the summations due to comparability concerns arising from federalism. For similar reasons, the German Länder DPA budget figures are augmented by a notional portion of the German federal DPAs based on their population ratios within Germany. All these figures are rounded to nearest $€ 0.00 \mathrm{M}$. 